\title{
THE POLITICS OF KNOWLEDGE ECONOMY AND SUSTAINABILITY OF TRIBAL KNOWLEDGE AND HEALTH IN INDIA
}

\author{
Kausiki Mukhopadhyay \\ Independent Scholar \\ Pallab Paul* \\ University of Denver \\ Indeesh Mukhopadhyay \\ University of Rochester
}

\begin{abstract}
With globalization, developing countries have been adopting the model of knowledge economy with its flagship features standardized patents and Corporate Social Responsibility (CSR). This model is supposed to deliver growth and equity through standardized patents and through market corrections of asymmetrical power between the corporations and general public via CSR. However, under this model, distributional equity has been declining. Instead of knowledge increasing and creating more equity, the traditional healthknowledge of tribal people (mostly poor) in India is being denuded along with innovation. This has been due to bio-piracy by multinational corporations. In addition, insensitive state policies that focus on growth policies at the expense of equity have exacerbated the situation. Under such circumstances, the health situation of tribal people is becoming dire. The authors argue that land redistribution and customized Intellectual Property rights (IPR) for communities as a whole may be the way forward provided there is political will.
\end{abstract}

Keywords: Knowledge economy; Corporate social responsibility; Sustainability; Tribal knowledge; India; Bio-piracy; Health equity

Received: 25 July 2019

Accepted: 22 May 2020

\section{INTRODUCTION}

With increasing globalization developing countries have been adopting the paradigm of knowledge economy for growth and development. India adopted this model under the aegis of the World Bank and the IMF at the beginning of the 90s when it faced balance of payments debacle. By mid 90s it had signed onto the signature flagship of the knowledge economy - Trade Related Intellectual Property Rights (TRIPS) (Sampat \& Amin, 2013; Sampat \& Shadlen, 2015; Sampat \& Shadlen, 2017). This meant that the Government of India (GOI) granted standardized intellectual property rights (IPR) of 'product' patents rather than customized 'process' patents to ensure economic growth. In this paper, through secondary research, we explore the consequences of these steps

\footnotetext{
- Pallab Paul, Ph.D, Professor of Marketing, Daniels College of Business, University of Denver, 2101 S. University Blvd, Room 497, Denver, CO 80208, USA. Phone: 1-303-871-4143. Fax: 1-303-871-2323. E-mail: ppaul@du.edu
} 
undertaken by the GOI for poor tribal people in India. We wish to evaluate whether growth-driven knowledge-economy policies have provided for their health equity.

To the best of our knowledge, no such study has been undertaken before. There have been studies only on tribal health knowledge (Patil \& Patil, 2005) and only on tribal health (Desai et al., 2017; Gamit et al., 2017; Kate, 2000), but no author has sought to link knowledge and health equity or their connection with the current paradigm of knowledge-economy. With this research gap in mind, our study will seek to fill in the gap in health policy studies. The tribal population (also called Adivasis) in India is significantly large - it is over 100 million or about $8.6 \%$ of the Indian population, according to the 2011 census. They are the indigenous people of India, historically remained outside the dominant Hindu civilization, and continued to be distinct as they escaped colonization by the British. Given their sheer size, it is important to investigate how the current knowledge economy is impacting the health equity of the tribal people in India.

What is the impact of knowledge economy or economic globalization (Brysk \& Mehta, 2017; SeoYoung, 2013; Wang, 2017) on tribal people's rights of access to health in India? In this paper we claim that under the aegis of knowledge economy health services and access to health has declined; social dislocation has increased; loss of biodiversity has occurred; patents of traditional knowledge of communities for the benefit of the communities through customized IPR has not occurred; and innovation by tribal people has declined under the stress of increasing 'health-poverty'. These facts have happened despite the presence of stores of 'health-knowledge' among tribal people, who are the most poor and marginalized in India. We highlight this case with the example of an economically fast growing state in India - Maharashtra. The idea is to demonstrate that under conditions of growth instead of wealth trickling down and increasing welfare and equity, 'healthpoverty' has increased. The decline in health has been associated with increasing state repression and rising extremism which make the positions of the tribal people's networks extremely vulnerable.

Focused on growth of exports of medicinal plants, the GOI denies tribal people access to forests, the vital source of medicinal herbs and the source of continuous innovation. Tribal people are simultaneously deprived of land on which they could have cultivated medicinal crops and access to forest resources which provide for cure for various kinds of diseases. This problem is not new the Forest Act of 1878 gave the State the right to reserve (expropriate, administer and keep tribal people out of) all forests in colonial India and consequently, between 1891 and 1910 one-third of all forests were reserved. Additionally, from 1889 the State started granting monopsonies to nontribal traders for the collection of forest produce and imposing duties on tribal collectors. Lately, this situation is further worsened by irresponsible corporate social responsibility (CSR) of pharmaceutical companies as demonstrated in bio-piracy of the poor's knowledge (Crane et al., 2008; Stohl et al., 2017) and failure to do benefit-sharing from the productive activities undertaken from that knowledge. Patents have helped lock in global inequalities (Carolan, 2008; Scholz \& Wolf, 2015; Wolf \& Scholz, 2017).

There is a severe lack of environmental CSR, environmental justice, grassroots eco-restoration as a way of life, shared value-creation, and a general lack of emphasis on human rights (Dyllick \& Rost, 2017; Montiel \& Delgado-Ceballos, 2014; Schönherr et al., 2017; Tomblin, 2009; Wang, 2017). While state and market has both failed to increase the distributional welfare of tribal people, some relief, however, come to them, particularly their women from dedicated non-governmental 
groups (NGOs) who provide for healthcare through deliberate social intervention (Mwangi, 2017; Shah \& Elliot, 2015; Umashankar \& Srinivasan, 2013). There are also NGOs that resist corporate biocolonization, such as, the NGO Navdanya by Vandana Shiva which call for democracy of seeds or the right to own seeds and farmers' rights to plant crops through traditional methods of cultivation (Salleh, 2006). However, NGOs in India are restricted in their activities as the government seeks to restrict them out of fear of politicization of NGOs and their ability to mobilize the common public (Brody et al., 2015; Kilby 2011; Kumaran, 2014; Rebecchi et al., 2016). Consequently, there are very few avenues left for the tribal people to access health equity.

We begin this paper with conceptual backgrounds on key term knowledge-economy in order to outline the assumptions behind the politics of knowledge economy. We then go on to describe the importance of knowledge communities and how such communities have been marginalized in the drive to create modern knowledge economy. In order to establish the negative impact of modern knowledge economy, it is first important to establish the repository of knowledge among the tribal population in the Indian state Maharashtra in order to establish how such knowledge is being denuded. We then follow it up with by describing the scenario of bio-piracy, state repression, and rising extremism to indicate the multiple ways in which unleashing of free-market knowledge economy has made the position of tribal people precarious.

Next, we provide some examples of health decline among the tribal population and NGO efforts to ameliorate the situation. We conclude with the advocacy that as part of ensuring distributional equity, the Indian government has to take measures to customize IPR for communities as a whole and provide all the necessary services needed for 'backward' labeled tribal groups to function within an unfettered free-market economy. Public policies should refocus on equity and make sure that growth does not come at the expense of equity.

\section{KNOWLEDGE ECONOMY}

With trade-globalization, Southern developing nations get increasingly embedded into a global economy. To catch up with the Northern leaders they are increasingly emulating the paradigm of the knowledge economy (Paul and Mukhopadhyay, 2010), which has become ubiquitous where economic growth is dependent on the information available, rather than the means of production. Before we explore the consequences of the knowledge economy, it is critical to understand the assumptions behind the model of the knowledge economy.

The model of the knowledge economy is propounded by neoliberal economists. First, they favor the operation of free market economy over state provision of public services. This is because they consider the state to be inefficient and corrupt and hence, prescribe state retrenchment. In contrast to state, an asocial, power-free, auto-regulated market is thought to be efficient and helps to provide for individual freedom and welfare (Atasay, 2015; Callaghan, 2015; Coleman, 2013; Lemke, 2001; Olssen, 2006; Pham \& Vo, 2019). All structural barriers for disadvantaged populations are overlooked.

Second, in neoliberal vision, utilitarian ethics of cost-benefit would encompass all domains of the social including communities which stand out for differing from any economic rationality. In doing so, neoliberals ignore all forms of market failure including negative externalities (such as, loss of 
biodiversity) and inability to provide for collective good (such as, healthcare.) They also fail to take into account morality that is altruistic and beyond utilitarianism, a morality that tends to define group affiliations. In this sense, neoliberalism disembeds the economy from the social.

Third, neoliberals emphasize the sustainable characteristic of knowledge. However, it emphasizes only knowledge that is 'intellectual,' discounting the 'physical labor' and 'natural resources' needed to create knowledge. Knowledge is also seen as individualized, utilitarian and commodifiable and hence, only codifiable 'scientific' knowledge is valued. This discounts a whole stream of non-codifiable traditional knowledge.

Fourth, neoliberals consider patents to be incentives for knowledge production of business. Hence, they support the highly skewed stringent standardized IPR inscribed in international treaty system TRIPS (Cottier, 2015; Sell, 2005; Urpelainen \& Van de Graaf, 2015). Coerced into accepting such a patent system (Cohen, 2008, 2017), developing states have been left with very little leverage for distributional issues (Khan \& Patomaki, 2010) and there has been a constant struggle over human rights in TRIPS implementation (Drahos \& Braithwaite, 2004; May, 2006; Sell, 2007). Standardized product patents replaced previous customized process patents and have led to commodification and privatization of scientific knowledge production (Baskaran \& Boden, 2008). This helps in providing for accumulation of wealth for corporations (Herstatt et al., 2008; Herstatt \& Tiwari, 2017; Narula \& Kodiyat, 2016).

Fifth, neoliberals believe that IPR provides incentives for innovation for individuals and increase their productive activity. This is expected to help develop human capital. IPR for communities is not considered an option. Critics point out that instead of market-driven innovation, if innovation is customized taking into account local social structures and history, IPR can be useful (Baskaran $\&$ Boden, 2008). However, given that only modern science is now considered science, traditional knowledge of indigenous societies are not given the protection of patents as it is not considered as science.

Sixth, in light of widespread inequity in developing states, neo-liberal economists put significant faith in corporate social responsibility (CSR) to rectify developmental issues. CSR is supposed to provide for market corrections for asymmetrical power. Corporations as individuals proactively and voluntarily take steps to demonstrate their adherence to rule of law and engage in stakeholder management in order to avoid the costs of government regulation and sanctions (Garcia et al., 2017; Hsiao, 2015; Lawrence \& Weber, 2013; Moura-Leite et al., 2014; Trivedi, 2016).

Lack of customized IPR for indigenous knowledge has generated perverted incentives for biopiracy or stealth of local knowledge. The way this happens is through 'bio-prospecting' of healing indigenous plants by corporate appointed scientists. The local scientists working within the purview and incentive structure of a multinational corporation use their local knowledge to network, through middlemen (Ramakrishnappa \& Krell, 2002) and tap into the knowledge of local indigenous communities without these groups being aware of what they are giving away in terms of proprietary rights. Once, a 'healing' plant is identified, the healing active ingredient in a healing plant is decoded through genome deconstruction by the scientists (Grain, 2007) This process is, ironically, a process similar to reverse engineering of synthetic drugs that used to be undertaken under the banner of process patents. Such a process was anathema for Western corporations, who considered it to be stealing of their knowledge, and it led to the institution of standardized patents 
in TRIPS. The fact that the same Western corporations are now conducting reverse engineering of tribal knowledge reveals the hypocrisy of CSR. The situation is further worsened by the fact that there are no significant attempts by businesses to share the benefits of such knowledge with the original knowledge preservers and developers of such healing systems.

Given this overall background, many have asserted that the current form of the knowledge economy shows modern forms of accumulation of surplus value along with primitive accumulation (Brass, 2011) of knowledge through dispossession of primary owners in the South which is rich in traditional knowledge (Brand \& Gorg, 2008; Gibb, 2007; Tyfield, 2008; Zeller, 2008). Trade has converted that which used to be traditionally immediately useful products into commodities for international exchange. But, since this trade is defined by highly asymmetric power relations between producers, consumers and intermediate appropriators of the products, the trading system instead of being a value-producing network has become a realm of highly contested value-capture (Love, 2007).

Due to the constant tension between individual and societal rights and the negative impact on human rights, we argue that instead of standardized IPR, if IPR is customized to local social dynamics (like local knowledge conservation), it may be more useful. IPR should serve a useful social purpose of increasing tribal peoples' political voice and socio-economic situation, ensuring developmental equity, and engendering radical and incremental innovations. In the meantime, in the absence of such measures, commerce instead of being a bond of union among nations and citizens, as visualized by the liberal world-view, has become the most fertile source of animosity and social conflict. Such conflict has been predicted by Polyani (2001) - he pointed out that disembedding the economy from its constitutive social base would give rise to counter-movements in the civil society.

\section{THE IMPORTANCE OF KNOWLEDGE COMMUNITIES}

Knowledge economy tends not to see knowledge as being embedded in relational networks which constitute an 'intellectual commons'. Nor is knowledge seen as functional for maintenance of a community in itself. However, Scheduled Tribes (STs), the most oppressed and poor people in India are not developed enough and dis-embedded from their communities enough to have individual patent based knowledge.

Beyond knowledge it is necessary to look at issues of access to forest land or 'natural capital' as the source of sustainability of such knowledge-base. Such knowledge-base helps to build human capital, engender innovations and sustain social capital (Aslund \& Starrin, 2014). But, the knowledge economy fails to take into account the initial inequity that arises due to lack of access to knowledge-bases due to lack of ownership or tenure of forestlands because of repressive government policies (Mukhopadhyay \& Paul, 2018). Moreover, land grabs for commercial purposes are on the rise in India. Under such situation, contra the knowledge economy prediction, instead of individual property rights being on the rise there is increasing loss of property right due to loss of ancestral lands by tribals.

There is lack of widespread alternative income opportunities for tribal people and they suffer from severe malnutrition. Non-surviving and sick populace can hardly care for forests and generate 
innovations. Moreover, lack of alternative income sources causes distress migration to take place. When Scheduled Tribes migrate, forests do not get conserved by those who have the best knowledge for it. This creates for a 'unique' Tragedy of the Commons where knowledge available is not efficiently used to preserve forests. Contra knowledge-economy prediction of welfare, there is unsustainable health outcomes despite the presence of traditional knowledge regarding health due to lack of access to knowledge resources. Tribal people are deprived of their right to life, and efficient human capital, as predicted by the knowledge economy, cannot be formed.

Considering the above mentioned background, it is important to look at the store of knowledge present in the state of Maharashtra and how such knowledge is being threatened by bio-piracy and government acts of unilateral conservation and commercial exploitation of forests.

\section{THE STORE OF KNOWLEDGE IN MAHARASHTRA}

Maharashtra is the third largest state in India (see the map in Appendix 1) and has the second largest tribal population of $10.2 \%$ (Kate, 2000). For tribal people, forests are critical sources for fodder, fuel wood and medicine. Herbal ethno-medicine tend to be a mixture of plants, animal products and minerals, along with various rituals and practices that are used in the process of administering them (Kulkarni \& Deshpande, 2011; Muruganandam et al., 2014). For illiterate and socio-economically backward, poorest of the poor population in India, such medicines are absolute lifeline for survival. Such knowledge is uncodified, has a base in the community, is oral and passed down from generation to generation. Hence, saving the utilization potential of such knowledge is very important.

Patil \& Patil (2005) record the ethnomedicinal practices of the tribes of Mahadeo Koli, Katkari, Bhils, Kunabi-kokona, Thakurs \& Warlis in the Nasik district of Western Ghats of Maharashtra. Antidotes in their various decoctions to counter snake-bites, scorpion-stings, gastro-intestinal disorders, diabetes, leucorrhea, cough-cold headache, kidney stone, pediatric vermifuge, etc., are recorded as diseases treated by the tribal people. Kosalge \& Fursule (2009) found that the Pawara tribal people living in Satpuda hills of Nandurbar district of Maharashtra regularly use 52 species of plants belonging to 36 families to cure diseases. Such diseases include "skin disorders, burn, diarrhea, jaundice, mouth ulcer, fever, joint pain, abdominal pain, piles, migraine, menstrual problems, urinary problems, wounds, dog bite, intestinal worms, and as anthelmintic and abortifacient" (p. 460-461). Bhardwaj et al. (2011) document 47 plants in Amravati and Yavatmal district in Maharashtra. The plants are used to treat conditions like inflammation, fever, hepatic disorder, hypertension, wounds, leprosy, TB, etc. (Brown et al., 2017). Furthermore Kamble et al. (2010) document the practices of the Bhilla tribe of Jalgaon, and Nandurbar districts of Maharashtra. They identify 127 plants belonging to 116 genera and 59 families of flowering plants and ferns used to treat diseases such as cholera, malaria in humans and curing cattle's stomach inflation. Similarly, Katkari tribes who live in the Thane and Raigad districts of Western Maharashtra use plants to cure both human and livestock diseases.

Jagtap et al. (2006) document the ethnomedicinal practices of the Korku tribe of Amravati district of Maharashtra (Bose et al., 2015). Korkus use 66 species of plants belonging to 40 families to reduce vaginal discharge, induce sterility, cure encephalitis, and stroke among humans; and fracture and prolapse in cattle. In the community, traditional healers or 'Bhumkas' transfer the 
knowledge of medicine to select teenagers who work as their assistants. Problem is that if the teenagers choose to leave their traditional way of life, not only is such knowledge lost, conservation of plants becomes problematic. Hence, it is critical to note that the authors document nine plant species that are on the endangered red-listed species.

When it comes to problems of knowledge access, the barriers are not just a lack of adequate modern infrastructure, it is also cultural exclusion of women by men in the communities from such knowledge base. Suroowan et al. (2017) document how women despite such exclusion have developed treatment expertise such as knowledge relating to pregnant and lactating mothers through their own initiatives. Given the increasing feminization of agriculture, such knowledge dissemination and preservation becomes critical for women.

In Maharashtra, the National Medicinal Plant Board, the all-India NGO Foundation for Revitalization of Local Health Tradition (FRLHT) and Pune district based NGO Rural Communes Medicinal Plant Conservation Centre (RCMPCC) have been involved in 13 projects working with tribal women and healers to conserve and document knowledge. The RCMPCC has created a systematic database on 326 medicinal plants, 465 herbal formulations, illness-specific database on 265 plants, a herbarium record of 804 species and initiated the People's Biodiversity Register to document women's and healers knowledge. As part of the resource institution of the State Medicinal Plant Board, it has conducted market study of 22 medicinal plants with the goal of providing benefit-sharing to the tribes (Holmukhe \& Antwal, 2017; Josyula et al., 2016; Shukla \& Gardner, 2006; Upadhya et al., 2014). Such conservation and developmental efforts are direly needed to ensure continuity of knowledge. Despite such efforts, threat in the form of loss of knowledge comes from bio-piracy which we explore next.

\section{BIO-PIRACY}

One of the first steps that the GOI took to counter bio-piracy was to create the Traditional Knowledge Digital Library (TDKL) to document the knowledge of plants and traditional remedies. However, mere documentation without an emphasis on customized patent for communities as a whole means that there is no guarantee that IPR issues will be protected from bio-piracy. Biopiracy occurs because of two things. First, tribal people do not know about the necessity of IPR to protect knowledge and often give it away for free to private entities. Second, biotechnological inventions being made, using traditional knowledge through identification of bioactive compounds, are often not protected as prior art in other countries, such as, the USA (Bala, 2011; Williams, 2017).

The documentation through TDKL happened as Indian scientists noted a disturbing trend of bioprospecting of natural healthcare solutions by foreign corporations. After searching the records of global trademark offices, Indian officials found 5,000 patents had been given for traditional medicinal plants, more than 2000 of which belonged to the Indian system of medicine. The companies involved had spent about $\$ 150$ million to get such patents, without providing any compensatory benefits to the original holders of such knowledge. This caused concern and raised eyebrows of the scientists. The cause for such surprise was that multinationals were spending millions on traditional remedies when many lobbies in the Western world denied the validity of such traditional forms of treatments (Ramesh, 2009). After documenting through TDKL, the GOI 
then licensed 200,000 local treatments as 'public property.' Such knowledge was free for use but, could not be sold as a 'brand.' This did not help in bringing specific benefits to specific communities who developed the knowledge over generations. Customized IPR with benefitsharing would have been helpful instead.

Given the vast store of traditional knowledge base in India, it is critical to note the history of biopiracy in India. India's fight against bio-piracy began in the mid-90s, ironically, at the time that the country signed onto product patent of TRIPS. The first case of bio-piracy was that of turmeric. Turmeric (Curcuma longa) has antibiotic, antioxidant, anti-inflammatory and coagulant properties. In 1995, two patents were filed by University of Mississippi Medical Center and one by Northwestern Flavors Inc. and Northwestern Chemical Company. The Indian body Council of Scientific and Industrial Research (CSIR) successfully appealed the decision to the US Patent and Trademark Office (USPTO) and got the patents revoked.

Beyond turmeric, there were several prominent bio-piracy cases, all of which did not get complete resolution. First in 1997, US company Rice Tec Inc. cross-bred 22 traditional varieties of rice from India and Pakistan. The company had 20 claims in its patent based on its novel rice lines developed from rice germplasm as well as those based on traditional farmer bred varieties. Most importantly, the company hijacked the traditional name of 'Basmati' for its new rice germplasm. After complaint from the Indian government, in 2001 the USPTO only allowed 5 claims and denied the usage of the term Basmati.

Three fights on bio-piracy are still ongoing. First is the claims made by Pioneer Hi-bred/DuPont International Inc. over mustard and 'Nap Hal' wheat variety by the Monsanto Seed Company. Second, in February 2011, famous Indian activist Vandana Shiva, her NGO Navdanya and the European NGO-platform 'No Patent on Seeds' jointly filed an opposition against European patent granted to Monsanto on melon that originated in India and was already registered in international seed banks (Shiva, 2011, 2012). Third, a significant fight has led to filing of charges against Monsanto over its Bt eggplant. In 2012, the Environment Support Group filed a lawsuit against St. Louis based Monsanto. The main charge is that Monsanto had not gotten permission to use the natural indigenous varieties of eggplant before modifying them for its Bt. version.

All the above mentioned facts point to the inability of the best attempts of CSR to act as a checkpoint against misuse of corporate power and the need for state monitoring and regulation. The flow of our argument is depicted in Appendix 2.

\section{GOVERNMENT REPRESSION AND COUNTER-MOVEMENTS}

Corporations are not the only entity acting as barriers to cultivation of tribal knowledge for benefits of the tribal people. The GOI under incentives of the knowledge economy has been denying access to forests and land to the tribal people for purposes of conservation; to develop healing plants for purposes of trade; develop standardized patents through research of healing plants; and to develop lands for commercial purposes in cahoots with major corporations. Some examples of such public policy stance are listed below. 
India's medicinal plants are under threat of becoming extinct due to indiscriminate wild collection by pharmaceutical companies (Ramakrishnappa \& Krell, 2002; Toda et al., 2016). According to Zoramsangi (2010), 90\% of India's medicinal plants that are consumed and exported are found in forest habitats. $90 \%$ of India's medicinal plants supply to international market is from wild stock, leading to serious depletion (Ganesan \& Bhatt, 2008). In India, 960 medicinal plants are reported to be in trade, out of which 335 wild medicinal plant have already been assessed to be threatened or near threatened (such as the Podophyllum Hexandrum which is used for chemotherapy) in one or more of 17 states in the country; 178 red-listed threatened species are still being traded in high volume; and some species are traded despite being on the GOI's negative list of exports and on the list of Convention on International Trade in Endangered Species of Wild Fauna and Flora (Baig, 2016; Ved \& Goraya, 2011). Hence, forest conservation is critical. What is also needed is regulation of pharmaceutical company activities. But given state retrenchment this has not occurred.

Given the threat of extinction, the GOI has been focusing heavily on conserving and propagating improved stock of medicinal plants. So far 20,000 medicinal plants have been recorded. The GOI with the help of international organizations such as the International Union for the Conservation of Nature and Natural Resources, and World Wide Fund, has established national parks, wild life reserves and botanic gardens to ensure in situ conservation of wild life and plants It has also used biotechnology to bio-prospect for genetic materials and conserve the material ex situ using tissue culture, in vitro propagation methods, protoplast fusion, embryo transfer, cryopreservation, and gene banks. These actions have helped identify medicinal plants of economic value and through domestication have helped to obtain uniform and high quality materials for export (Joshi et al., 2010).

Conservation of medicinal plants is highly centralized in India with the GOI controlling access to forests. The GOI has set up National and 35 State Medicinal Plant Boards to conserve the medicinal plants. Between the periods of 2001-2006, the GOI has sanctioned 4,254 projects under two major schemes, contractual and promotional farming. In promotional category projects include cultivation and establishment of herbal gardens; in situ conservation; raising of quality planting material; research and development including biotechnology or tissue-culture, genetic, molecular and chemical compound studies, and pathological studies; dissemination of information; education and communication; marketing and value-addition (Kala, 2017; Kala \& Sajwan, 2007; Rathi et al., 2015).

The thrust of GOI's conservation is more about commercial exploitation of medicinal plants, rather than delivering the fruits of such conservation as medicines for ameliorating the health conditions of the poor. Preservation of India's $19.39 \%$ of forest area is critical. However, as Vasisht \& Karan (2003) point out, this preservation has to go beyond preserving germplasms in gene banks, investigation in pharmacology and biotechnology through the CSIR and regional laboratories. The GOI needs to allow the tribal people, who have the best knowledge for conservation, to conserve medicinal plants through proper ownership of forests. However, given the mainstream view that their knowledge is not 'scientific' such steps fail to occur.

A key problem with GOI's conservation is the method it uses under the rules of the regime Reduced Emissions from Deforestation and Degradation (REDD+). This is done through creation of commercial monocultures on forest lands. Commercial monocultures are plantations of high-value 
single species of trees whose timber is used for trading. All such trading comes at the price of tribal people losing access to their ancestral lands (Datta, 2016; Jha, 2018). The famous eco-feminist Vandana Shiva is a strong critic of the GOI's adherence to neoliberal policies of REDD+. She opposes the privatization and commodification of nature through conversion of forests into carbon markets as it leads to loss of access to forests for tribal people and to degradation of biodiversity of forests. The focus only on carbon sequestration, or only biomass production, as part of the project of REDD+, reduces the rich diverse forest eco-systems as they get replaced with commercial monocultures. Monocultures reduce the rich biodiversity that provides for a variety of medicinal plants (Lang, 2010).

Now let's look at the issue of land grabs for commercial exploitation. Despite GOI efforts, instead of forest land preservation, forests are still being depleted and land access for tribal people is being denuded through land grabs. Typically land is grabbed in the name of national interests. Such national interests are, for example, vested in issues of raising plantation for timber-logging and bio-diesel/bio-fuel (Kher, 2005; Mishra, 2017a, 2017b); conservation efforts to create carbon-sink projects in tune with the demands of the international regime REDD+; creation of Special Economic Zones (SEZ) for industrial development (Kaleji et al., 2017; Oza, 2010); development of nuclear projects for electricity generation; building of dams for generation of electricity; increasing agricultural land under cultivation; mining, tourism; and so on. According to Walker (2008), more than 500,000 hectares of forestland was seized for development projects, between 2001 and 2006 more than the previous 20 years aggregated together (Ahasan \& Gardner, 2016; Gardner \& Gerharz, 2016).

The loss of access to forests due to land grabs impacts tribal people severely by limiting health welfare and sustainable livelihood. Often such livelihood access is restricted by three factors. First, tribal people are deprived of legal as well as traditional, customary land rights by restrictive forest access. The professed aim of technocrats in undertaking such activities is 'scientific' modes of conservation and proper 'productive' usage of forest-land (Poddar et al., 2011; Tayal, 2015). Second, there is often arbitrary and non-democratic or highly partisan interest-oriented stateregulations on land use (Kennedy, 2015; Kennedy \& King, 2011; Stern \& Coleman, 2015). This tends to be a reflection of the elite capture of state resources, governance structures and development processes. Third, the occurrence of forcible state acquisitions of land and violent evictions of traditional dwellers from the 'occupied' land in the name of national interest (Ramdas \& Ghotge, 2007; Raza et al., 2016). This prevents tribal people from harvesting non-timber forest products for food and medicinal purposes.

Forest laws in India have typically been repressive (Poddar et al., 2011). But the GOI faces strong push-back from the civil society. The push-back is both peaceful and violent. The tribal protest against loss of access to forests has often taken violent form as can be seen in the Maoist movements. Land grabs provided the spark for widespread Maoist activities, covering 600 districts or $40 \%$ of the geographical area of India in 2007. This is because peaceful protests under the banner of grass-root organization the National Alliance of People's Movements have failed to stop state violence (Walker, 2008). In the presence of extremism, knowledge dwindles. This is contra knowledge-economy prediction that knowledge is renewable and sustainable. 
Under above mentioned conditions, knowledge flow among tribal folk and their networks get disrupted and innovation and conservation is put on the back-burner. In fact, violence and poverty bring about extreme crisis of health among the tribes.

\section{HEALTH WELFARE OF TRIBES IN MAHARASHTRA}

Maharashtra has the second largest concentration of poor ST population. But it is also considered a fast-growing high income state with a per capita income per annum of Rs. 32,170 (Khandare et al., 2008; Nerkar et al., 2015). According to Pitre et al. (2009), from an average 5\% per year growth from 1993-2001, growth increased to 7.8\% in 2002-2007. But despite growth, the STs have miserable health equity because of poverty. It is important to note that health is a state subject (Shrivastava et al., 2013, 2015a, 2015b) and hence, what happens in the state is significantly attributable to the state's actions. Currently, Maharashtra government spends only $0.48 \%$ of GDP on health. In 1996, Maharashtra's health expenditure as a percentage of total expenditure was $4.56 \%$, but by 2005 it had declined to $3.51 \%$ (Jain, 2010).

To understand the situation of the STs, it is important to track some statistics. According to www.nird.org.in, in Maharashtra the poverty levels of STs actually rose between 1993-94 and 2004-05 from 50.38\% to 56.6\% while the rates for all groups dropped. Hence it is not surprising that across Maharashtra compared to other oppressed groups, STs have high incidences of severe stunting, stunting, severe wasting, wasting, severe underweight, and underweight problems. For example, the respective figures for Scheduled Castes (SCs) for the mentioned incidences for under5 children are $23.4 \%, 55.2 \%, 6.6 \%, 20.2 \%, 13.5 \%$ and $41.7 \%$. In comparison, the corresponding figures for STs are 30\%, 57.8\%, 5.6\%, 18.9\%, 21.2\% and 53.2\%, respectively (Pitre et al., 2009). According to Dholakia \& Khurana (1983), starvation is widespread across India, but as we point out STs suffer the worst lot.

In Maharashtra among tribal population, infant mortality rate is $59 \%$, crude death rate is $7.9 \%$, maternal mortality rate is $2 \%$, low-birth weight babies is $28 \%$, family size is $3.8 \%$ and delivery by trained birth assistants instead of doctors is $86 \%$ (Kate, 2000). Kate (2000) also points out that deficiency of essential components in tribal diet leads to micronutrient deficiencies and protein calorie malnutrition. Goiter is endemic in some of the tribal areas due to such diet deficiencies. Water borne and communicable diseases, such as dysentery and parasitic infections are very common among the tribal people. This in turn leads to morbidity and malnutrition. Tuberculosis and malaria are major problems in many tribal areas. There is a high prevalence of genetic disorders like sickle cell anemia and thalassemia.

According to www.malariasite.com, malaria is endemic among the tribal population despite tribals having knowledge about cure for malaria. According to the site, side effects of urbanization and industrialization, especially water development projects have created for extensive malaria vector breeding sites. The malaria vector has predominantly become the P. falciparum vector which is resistant to insecticides and anti-malarial drugs. According to the site, at the all-India level, 90\% of malaria deaths are in rural areas and $86 \%$ occurred at home without medical attention. This can be attributed to lack of affordability of high-priced synthetic drugs due to standardized patents and the lack of access to non-traditional knowledge drugs due to lack of access to forests and lack of customized patents. 
Beyond broad-scale statistics it is important to track micro-studies to understand the tribal situation. Vlasoff et al. (2013) argued India's tribal population is at considerable risk of sexually transmitted diseases, particularly HIV/AIDS due to their relatively open sexual mores compared to traditional Indian society. The authors conducted a study of tribal and other rural people in the Satara district of Maharashtra. Compared to the all-Maharashtra infection rate of $0.5 \%$, this district had a very high incidence of $2 \%$ HIV positive women. Tribal people were found to have much less knowledge about HIV than rural respondents so that they had high stigma against people with the disease, particularly against women. The authors conclude that fear and denial in the tribal communities and an increase in high-risk behavior indicate that tribal communities are in early phase of an HIV epidemic. STs are also an emergent high-risk group because of displacement and migration into mainstream society for employment opportunities (Das \& Kumar, 2016; Nanjunda \& Dinesha, 2011). Despite HIV/AIDS being a major epidemic in India, the GOI refuses to acknowledge it as an epidemic. This means that it fails to evoke the TRIPS flexibility clause whereby a government can declare national emergency and procure drugs at drastically reduced prices to treat the epidemic (Löfgren, 2017; Sell, 2007). Corporate pressure against breaking of patents prevents the government from taking active intervention.

An NGO that works with rural and tribal health in Maharashtra is the Comprehensive Rural Health Project (CRHP). CRHP Started in 1990 with community-based program in the village of Jamkhed in the Bhandardara district to tackle tribal health problems. Given its success in this venture, CRHP was approached by the Maharashtra state government in 2004 to develop similar programs in seven other tribal districts. Their main objective has been to promote holistic health through both preventive (health education) and curative approaches especially for women and children. For complicated diseases such as TB, leprosy and HIV/AIDS that require in-patient hospital treatment, the local health workers of CRHP refer to the government Primary Health Care centers and hospitals. But trained health workers can take care of basic issues such as child health, nutrition, safe deliveries and hygiene. In trying to achieve such activities CRHP has also focused on creating self-help women's groups ("What is CRHP?", 2014).

NGOs working with government structures have made some changes. For example, MAHAN conducted a study in the Melghat, Thane region of Maharashtra and found $50 \%$ children were underweight. Under its recommendation and directive by the state High Court, the government now provides special facilities such as 'Village Child Development Center' to serve the underweight with appropriate diet intervention, instead of merely hospitalizing them. MAHAN also brought about changes in antibiotic use of ASHA workers. The workers were not advised to give antibiotics to children in the villages. Under MAHAN's recommendation, the state government has now approved the government workers' usage of drugs like Hematoxylin for children suffering from pneumonia and neonatal sepsis. This has helped to reduce child mortality ("Policy changes due to MAHAN", n.d.). Despite NGO help, the overall figures stated above, shows that the tribal condition is still very dire. NGO activism is significantly restricted in India and this prevents more widespread intervention.

\section{CONCLUSION}

Knowledge economy advocates propound that there will inevitably be winners and losers of reform and efficiency. But what its proponents fail to predict is that losers emerge even when they have 
valuable assets to compete in a free-market economy due to the power structure of society. The tribal population in India, despite being the poorest and marginalized, has rich depositories of knowledge. If IPR is customized for such populations, they can enjoy the benefits of free-market economy and be actively involved in sustainable conservation. But to do so, there is a requirement of government intervention. Market through CSR has failed to deliver the benefits of such knowledge and protect the tribal population through provision of healthcare services. Market failure means that the government has to actively step in and protect the tribal people from having their right to life being decimated. It needs to actively redistribute land to tribal people to enable self-empowerment through innovation and self-provision of healthcare and provide them with public healthcare services. It also needs to reverse the historically rooted oppression and exploitation of tribal society by the political and economic interests. Unlike neo-liberals, liberals like Rawls prescribed significant state enforcement for ensuring justice (Abbey \& Spinner-Halev, 2013; Goncalves, 2017) - active intervention is needed to balance growth with equity. Growth does not automatically lead to equity.

\section{REFERENCES}

Abbey, R., \& Spinner-Halev, J. (2013). Rawls, mill and the puzzle of political liberalism. The Journal of Politics, 75(1), 124-136.

Ahasan, A., \& Gardner, K. (2016). Dispossession by 'development': corporations, elites and NGOs in Bangladesh. South Asia Multidisciplinary Academic Journal, 13, 1-17.

Aslund, C., Starrin, B., \& Nilsson K. W. (2014). Psychosomatic symptoms and low psychological well-being in relation to employment status: the influence of social capital in a large crosssectional study of Sweden. International Journal for Equity in Health, 13(22), 1-10.

Atasay, E. (2015). Neoliberal multiculturalism embedded in social justice education: Commodification of multicultural education for the 21 st century. Journal for Critical Education Policy Studies, 12(3), 171-204.

Baig, B. A. (2016). Demographic studies on select threatened medicinal plants of Kashmir Himalaya, India (Doctoral dissertation, Pondicherry University).

Bala, A. (2011). Traditional Knowledge and Intellectual Property Rights: An Indian Perspective. Available at SSRN 1954924.

Baskaran, A., \& Boden, R. (2008). Knowledge capital and globalization: Towards a new conceptual model. Research Policy, ox.ac.uk.

Bhardwaj, M., Bhardwaj, L., Trigunayat, K., \& Trigunayat, M. M. (2011). Insecticidal and wormicidal plants from Aravalli hill range of India. Journal of Ethnopharmacology, 136(1), 103-110.

Bose, D., Roy, J. G., Mahapatra, S. D., Datta, T., Mahapatra, S. D., \& Biswas, H. (2015). Medicinal plants used by tribals in Jalpaiguri district, West Bengal, India. Journal of Medicinal Plants, 3(3), 15-21.

Brand, U., \& Gorg, C. (2008). Post-Fordist governance of nature: The internationalization of the state and the case of genetic resources - A neo-Poulantzian perspective. Review of International Political Economy, 15(4), 567-589.

Brass, T. (2011). Primitive accumulation, capitalist development and socialist transition: Still waiting for Godot?. Journal of Contemporary Asia, 41(1), 1-24. 
Brody, C., De Hoop, T., Vojtkova, M., Warnock, R., Dunbar, M., Murthy, P., \& Dworkin, S. (2015). The effects of economic self-help group programs on women's empowerment: A systematic review. Campbell Systematic Reviews, 11(19).

Brown, P. N., Lund, J. A., \& Murch, S. J. (2017). A botanical, phytochemical and ethnomedicinal review of the genus Mitragyna korth: Implications for products sold as kratom. Journal of Ethnopharmacology, 202, 302-325.

Brysk, A., \& Mehta, A. (2017). When development is not enough: structural change, conflict and gendered insecurity. Global Society, 31(4), 441-459.

Callaghan, L. (2015). Sri Lanka's' widows of war heroes' and the governmentality of empowerment (Doctoral dissertation, University of Toronto).

Carolan, M. S. (2008). Making patents and intellectual property work: The asymmetrical harmonization of TRIPS. Organization \& Environment, 21(3): 295-310.

Cohen, E. (2017). 8 Private arbitration as a mechanism for the construction of contractual norms in private-public relationships. The Politics of Private Transnational Governance by Contract, 151.

Cohen, E. (2008). Constructing power through law: Private law pluralism and harmonization in the global political economy. Review of International Political Economy, 15(5), 770-799.

Coleman, W. (2013). What was 'new' about neoliberalism? Economic Affairs, 33(1), 78-92.

Cottier, T. (2015). Working together towards TRIPS. World Trade Organization (WTO). Retrieved from https://www.wto.org/english/res_e/booksp_e/trips_agree_e/ chapter_4_e.pdf

Crane, A., Matten, D., \& Moon, J. (2008). Ecological citizenship and the corporation: politicizing the new corporate environmentalism. Organization \& Environment, 21(4), 371-389.

Das, N., \& Kumar, R. (2016). Role of non-governmental organizations in healthcare sector of India. Health Economics Division, Public Health Foundation of India (PHFI). Retrieved from https://www.researchgate.net/publication/309487015_Role_of_Non-Governmental Organizations in_Healthcare_Sector_of India?channel $=\overline{\text { doi\&linkId }}$ $=5812 \mathrm{fdf} 208 \mathrm{ae} 29942 \mathrm{f3ea} 038 \&$ showFulltext $=$ true

Datta, S. (2016). Continuing the forest conservation debate. Economic \& Political Weekly, 51(4), 49.

Desai, G., Anand, A., Shah, P., Shah, S., Dave, K., Bhatt, H., ... \& Modi, D. (2017). Sickle cell disease and pregnancy outcomes: A study of the community-based hospital in a tribal block of Gujarat, India. Journal of Health, Population and Nutrition, 36(1), 3.

Dholakia, N., \& Khurana, R. (1983). Public policy toward essential consumption items: generalization from the Indian experience. Journal of Public Policy and Marketing, 2(1), 171-182.

Drahos, P., \& Braithwaite, J. (2004). Who owns the knowledge economy?: Political organising behind TRIPS. The Corner House.

Dyllick, T., \& Rost, Z. (2017). Towards true product sustainability. Journal of Cleaner Production, 162, 346-360.

Gamit, B., Patel, A., Shah, P., \& Padsala, S. (2017). Autopsy findings and pattern of mortality in undiagnosed sickle cell disease patients. International Journal of Community Medicine and Public Health, 3(5), 1094-1100.

Ganesan, S., \& Bhatt, R. Y. (2008). Qualitative nature of some traditional crude drugs available in commercial markets of Mumbai, Maharashtra, India. Ethnobotanical Leaflets, 12, 348360. 
Garcia, A. S., Mendes-Da-Silva, W., \& Orsato, R. J. (2017). Sensitive industries produce better ESG performance: evidence from emerging markets. Journal of Cleaner Production, 150, 135-147.

Gardner, K., \& Gerharz, E. (2016). Land, 'development' and 'security' in Bangladesh and India: an introduction. South Asia Multidisciplinary Academic Journal, (13).

Gibb, H. (2007). Gender dimensions of intellectual property and traditional medicinal knowledge. UNDP. Asia-Pacific Trade and Investment Initiative.

Goncalves, E. (2017). The need for comprehensive liberalism (Doctoral dissertation, Boston College. Graduate School of Arts and Sciences).

Grain (2007). Bio-piracy: A System of Appropriation. Grain.org. Retrieved from https://www.grain.org/article/entries/603-bio-piracy-a-system-of-appropriation

Herstatt, C., \& Tiwari, R. (2017). India's emergence as a lead market for frugal innovations: An introduction to the theme and to the contributed volume. In Lead Market India (pp. 1-10). Springer, Cham.

Herstatt, C., Tiwari, R., Ernst, D., \& Buse, S. (2008). India's national innovation system: Key elements and corporate perspectives. Working Paper \# 51. Institute of Technology and Management Hamburg University of Technology. Retrievedf from www.globalinnovation.net.

Holmukhe, S. S., \& Antwal, P. N. (2017). Use of indigenous medicinal plants by tribal women for treatment of digestive disorder. Journal of Medicinal Plants, 5(1), 326-330.

Hsiao, P. C. (2015). Usefulness of integrated reporting concepts to investment decision-making: empirical evidence from Taiwan (Doctoral dissertation, University of Waikato, New Zealand).

Jagtap, S.D., Deokule, S.S., \& Bhosle, S.V. (2006). Some unique ethnomedicinal uses of plants used by the Korku tribe of Amravati district of Maharashtra, India. Journal of Ethnopharmacology, 107(3), 463-469.

Jain, H. (2010). Health sector reforms and health poverty. Social Change, 40(1), 61-78.

Jha, D. (2018). The Green India Mission (GIM): A roadmap for neo-liberal exploitation in forest. International Institute of Social Studies. Retrieved from http://www.academia.edu/ 1028689/The_Green_India_Mission_GIM_A_Roadmap_for_Neoliberal_Exploitation_in_Forest

Joshi, R., Nailwal, T. K., Tewari, L. M., \& Shukla, A. (2010). Exploring biotechnology for conserving Himalayan biodiversity. Life Science Journal ACTA - Zhenzhou University Overseas Edition, 7(3), 20-28.

Josyula, K. L., Sheikh, K., Nambiar, D., Narayan, V. V., Sathyanarayana, T. N., \& Porter, J. D. (2016). "Getting the water-carrier to light the lamps": Discrepant role perceptions of traditional, complementary, and alternative medical practitioners in government health facilities in India. Social Science \& Medicine, 166, 214-222.

Kala, C. P. (2017). Traditional health care systems and herbal medicines. European Journal of Environment and Public Health, 1(1), 03.

Kala, C. P., \& Sajwan, B. S. (2007). Revitalizing Indian systems of herbal medicine by the National Medicinal Plants Board. Current Science, 93(6).

Kaleji, L. K., Hesam, M., \& Kazemi, M. (2017). An analysis of influential factors on tourism destinations competitiveness. Journal of Environmental Management \& Tourism, 8(218)), 393. 
Kamble, S. Y., Patil, S. R., Sawant, P. S., \& Sawant, S. (2010). Studies on plants used in traditional medicine by Bhilla tribe of Maharashtra. Indian Journal of Traditional Knowledge, 9(3), 591-598.

Kennedy, J. (2015). The socioeconomic determinants of natural resource conflict: Minerals and Maoist insurgency in India. Society \& Natural Resources, 28(2), 149-164.

Kate, S. L. (2000). Health problems of tribal population groups from the state of Maharashtra. Immunohaematology Bulletin. $\quad$ Retrieved from http://sickle.bwh.harvard.edu/india_scd.html

Kennedy, J. J., \& King, L. P. (2011). Understanding the conviction of Binayak Sen: Neocolonialism, political violence and the political economy of health in the central Indian tribal belt. Social Science \& Medicine, 72(10), 1639-1642.

Khan, H., \& Patomaki, H. (2010). A reconstructive critique of IPE and GPE from a critical scientific realist perspective: An alternative Keynesian-Kaleckian approach. http://mpra.ub.uni-muenchen.de/49517/

Khandare, A .L., Siruguri, V., Rao, A., Venkaish, K., Reddy, G., \& Rao, G. S. (2008). Diet and nutrition status of children in four tribal blocks of Thane district of Maharashtra, India (nutrition status of children). Pakistan Journal of Nutrition, 7(3), 485-488.

Kher, R. (2005). Biofuels: the way ahead. Economic and Political Weekly, 40(51), 5376-5378.

Kilby, P. (2011). NGOs in India: the challenges of women's empowerment and accountability. USA: Routledge.

Kosalge, S. B., \& Fursule, R. A. (2009). Investigation of ethnomedicinal claims of some plants used by tribals of Satpuda hills in India. Journal of Ethnopharmacology, 121(3), 456-461.

Kulkarni, C. G., \& Deshpande, A. (2011). Folk therapies of Katkaris from Maharashtra. Indian Journal of Traditional Knowledge, 10(3), 554-558.

Kumaran, M. (2014). Roles, responsibilities, and trends of NGOs in women empowerment. Indian Journal of Public Administration, 60(3), 588-597.

Lang, C. (2010). Monocultures on the march in Southeast Asia. Chrislang.org. Retrieved from https://chrislang.org/2010/09/19/monocultures-on-the-march-in-southeast-asia/

Lawrence, A. T. \& Weber, J. (2013). Business and society: stakeholders, ethics, and public policy. NY: McGraw-Hill.

Lemke, T. (2001). The birth of bio-politics: Michel Foucault's lecture at the Collège de France on neo-liberal governmentality. Economy and Society, 30(2), 190-207.

Love, R. (2007). Corporate wealth or public health? WTO/TRIPS flexibilities and access to HIV/AIDS antiretroviral drugs by developing countries. Development in Practice, 17(2), 208-219.

May, C. (2006). Review essay: social limits to the commodification of knowledge: ten years of TRIPS. Journal of International Economics, 2(1), 91-108.

Mishra, S. N. (2017a). Explicating green biofuel policy across Indian states. Green Initiatives for Business Sustainability and Value Creation, 164.

Mishra, S. N. (2017b). Institutional design of biofuel development across world. SSRN Electronic Journal. doi:10.2139/ssrn.2945381

Montiel, I. \& Delgado-Ceballos, J. (2014). Defining and measuring corporate sustainability: Are we there yet? Organization \& Environment, 27(2), 113-139.

Moura-Leite, R., Robert, C., Padgett, C., \& Galan, J. I. (2014). Stakeholder management and nonparticipation in controversial business. Business \& Society, 53(1), 45-70.

Mukhopadhyay, K. \& Paul, P. (2018), Pharmaceutical growth versus health equity in India: When markets fail. Journal of Public Health. doi: 10.1007/s10389-018-0969-6 
Muruganandam, S., Kadirvelmurugan, V., Selvaraju, A., Rathinakumar, S., \& Ravikumar, S. (2014). Ethnomedicinal plants used by the Malayali tribals in Jawadhu hills of Thiruvannamalai district, Tamil Nadu, India. Journal of Natural Product and Plant Resources, 4, 55-60.

Mwangi, L. W. (2017). The influence of social marketing on consumer behavior: A case of Nyeri town constituency (Doctoral dissertation, Strathmore University).

Nanjunda, D. C, \& Dinesha, P. T. (2011). Role of non-governmental organizations (NGOs) interventions on tribal health: Some annotations from grass root level. International NGO Journal, 6 (9), 193-196.

Narula, R., \& Kodiyat, T. P. (2016). How weaknesses in home country location advantages can constrain EMNE growth: The example of India. Multinational Business Review, 24(3), 249-278.

Nerkar, S. S., Pathak, A., Lundborg, C. S., \& Tamhankar, A. J. (2015). Can integrated watershed management contribute to improvement of public health? A cross-sectional study from hilly tribal villages in India. International Journal of Environmental Research and Public Health, 12(3), 2653-2669.

Olssen, M. (2006). Understanding the mechanisms of neoliberal control: lifelong learning, flexibility and knowledge capitalism. International Journal of Lifelong Education, 25(3), 213-230.

Oza, R. (2010). Special economic zones: space, law and dispossession. In India's New Economic Policy: A Critical Analysis, Ahmed W, Kundu A, Peet R (eds). Hoboken, NJ: Routledge.

Patil, M. V., \& Patil, D. A. (2005). Ethnomedicinal practices of Nasik district, Maharashtra. Indian Journal of Traditional Knowledge, 4(3), 287-290.

Paul, P., \& Mukhopadhyay, K. (2010). Growth via intellectual property rights versus gendered inequity in emerging economies: an ethical dilemma for international business. Journal of Business Ethics, 91, 359-378.

Pham, T. N., \& Vo, D. H. (2019). The impact of earnings from the elderly women on household income inequality in Vietnam. International Journal of Business and Society, 20(2), 451462.

Pitre, A., Lakshmikanth, H., Kamble, M., Sardeshpande, N., Padhye, R., \& Mishra, S. (2009). Nutritional crisis in Maharashtra. Report prepared by SATHI for Maharashtra Health Equity and Rights Watch.

Poddar, A.K., Mukherjee, S., \& Nandy, D. (2011). Forest laws and policies in India. N. Delhi: Regal Publications.

Policy changes due to MAHAN.MAHAN Trust. Retrieved from https://www.mahantrust.org/policy-changes

Ramakrishnappa, K., \& Krell, R. (2002) Impact of cultivation and gathering of medicinal plants on biodiversity: Case studies from India. Retrieved from http://www.fao.org/docrep/005/y4586e/y4586e09.htm.

Ramdas, S. R., \& N. S. Ghotge. (2007). Whose rights? Women in pastoralist and shifting cultivation communities: A continuing struggle for recognition and rights to livelihood resources. In Women's Livelihood Rights: Recasting Citizenship for Development, Sumi K. (ed.) New Delhi: Sage Publications.

Ramesh, R. (2009). India fights pharmas stealing natural medicine and patenting it. Prorev.com. Retrieved from http://prorev.com/2009/04/india-fights-pharmas-stealing-natural.html 
Rathi, R. S., Roy, S., Mehta, P. S., Misra, A. K., Negi, K. S., \& Rayal, A. (2015). Traditional uses of medicinal plants of Cooch Behar and Jalpaiguri districts of west Bengal, India. Indian Forester, 141(4), 461-468.

Raza, M. A., Younas, M., \& Schlecht, E. (2016). In vitro efficacy of selected medicinal plants from Cholistan desert, Pakistan, against gastrointestinal helminths of sheep and goats. Journal of Agriculture and Rural Development in the Tropics and Subtropics (JARTS), 117(2), 211-224.

Rebecchi, A., Gola, M., Kulkarni, M., Lettieri, E., Paoletti, I., \& Capolongo, S. (2016). Healthcare for all in emerging countries: A preliminary investigation of facilities in Kolkata, India. Annali Dell'istituto Superiore Di Sanita, 52(1), 88-97.

Salleh, A. (2006). Resistance to corporate biocolonization, book review. Organization \& Environment, 19(3), 406-410.

Sampat, B. N., \& Shadlen, K. C. (2017). Secondary pharmaceutical patenting: A global perspective. Research Policy, 46(3), 693-707.

Sampat, B. N., \& Shadlen, K. C. (2015). TRIPS implementation and secondary pharmaceutical patenting in Brazil and India. Studies in Comparative International Development, 50(2), 228-257.

Sampat, B. N., \& Amin, T. (2013). How do public health safeguards in India patent law affect pharmaceutical patenting in practice? Journal of Health Politics, Policy and Law, 38(4), 735-755.

Scholz, S., \& Wolf, K. (2015). Transformation of an order through reversal of a norm-hierarchy: The protection of intellectual property and the right to health. Social Science Open Access Repository, 131, 1-30. Retrieved from https://www.ssoar.info/ssoar/handle/document/ 44918

Schönherr, N., Findler, F., \& Martinuzzi, A. (2017). Exploring the interface of CSR and the sustainable development goals. Transnational Corporations, 24(3), 333.

Sell, S. K. (2005). An introduction to TRIPS. In Private power, public law: the globalization of intellectual property rights (pp. 7-20). Cambridge, U.K.: Cambridge University Press.

Sell, S. K. (2007). TRIPS-plus free trade agreements and access to medicines. The Liverpool Law Review, 28, 41-75.

Seo-Young, C. (2013). Integrating equality: globalization, women's rights, and human trafficking. International Studies Quarterly, 57, 683-697.

Shah, G., \& Elliot, E. A. (2015). The impact of socio-cultural factors on professional aspirations in emerging markets. International Journal of Employment Studies, 23(1), 24.

Shiva, V. (2011). Opposition to Monsanto's Patent on Indian Melon | no patents on seeds. Nopatents-on-seeds.org. Retrieved from http://no-patents-on-seeds.org/en/information/ news/opposition-monsanto-s-patent-indian-melon

Shiva, V. (2012). Opposition by Vandana Shiva. No-patents-on-seeds.org. Retrieved from http://no-patents-on-seeds.org/sites/default/files/patente/einspruch/ oppo_melon_vandana_shiva.pdf

Shrivastava, S., Shrivastava, P. S., \& Ramasamy, J. (2013). Implementation of public health practices in tribal populations of India: challenges and remedies. Healthcare in Lowresource Settings, 1(1).

Shrivastava, S., Shrivastava, P. S., \& Ramasamy, J. (2015a). Facilitating accreditation of health care establishments: A holistic tool for ensuring benefits to employers, employee and patients. Sifa Medical Journal, 2(1), 27. 
Shrivastava, S., Shrivastava, P.S., \& Ramasamy, J. (2015b). Mainstreaming of Ayurveda, Yoga, Naturopathy, Unani, Siddha, and Homeopathy with the health care delivery system in India. Journal of Traditional and Complementary Medicine, 5(2), 116-118.

Shukla, S. \& Gardner, J. (2006). Local knowledge in community-based approaches to medicinal plant conservation: lessons from India. Journal of Ethnobiology and Ethnomedicine, 2(20), 1-9.

Stern, M. J., \& Coleman, K. J. (2015). The multidimensionality of trust: applications in collaborative natural resource management. Society \& Natural Resources, 28(2), $117-$ 132.

Stohl, C., Etter, M., Banghart, S., \& Woo, D. (2017). Social media policies: implications for contemporary notions of corporate social responsibility. Journal of Business Ethics, 142(3), 413-436.

Suroowan, S., Javeed, F., Ahmad, M., Zafar, M., Noor, M. J., Kayani, S., ... \& Mahomoodally, M. F. (2017). Ethnoveterinary health management practices using medicinal plants in south Asia-a review. Veterinary Research Communications, 41(2), 147-168.

Tayal, V. (2015). Legislating forest ecology in India. Environmental Crisis and Conservation, 148.

Toda, M., Salgado, E. L. R., \& Masuda, M. (2016). Assessing medicinal plants as the linkage between healthcare, livelihood and biodiversity: A case study from native villages surrounding a second-tier city in the central Peruvian Amazon. Tropics, 25(2), 53-65.

Tomblin, D. C. (2009). The ecological restoration movement: diverse cultures of practice and place. Organization \& Environment, 22(2), 185-207.

Trivedi, S. (2016). Operationalizing peace through commerce: toward an empirical approach. Business Horizons, 59(5), 525-532.

Tyfield, D. (2008). Enabling TRIPS, the pharma-biotech-university patent coalition. Review of International Political Economy, 15(4), 535-566.

Umashankar, N. \& Srinivasan, R. (2013). Designing social interventions to improve newcomer adjustment: insights from the Indian sex-worker community. Journal of Public Policy and Marketing, 32(2), 271-285.

Upadhya, V., Hegde, H. V., Bhat, S., \& Kholkute, S. D. (2014). Non-codified traditional medicine practices from Belgaum region in southern India: present scenario. Journal of Ethnobiology and Ethnomedicine, 10(1), 49.

Urpelainen, J., \& Van de Graaf, T. (2015). Your place or mine? Institutional capture and the creation of overlapping international institutions. British Journal of Political Science, 45(4), 799-827.

Vasisht, K., \& Karan, M. (2003). The status of medicinal and aromatic plants in India and Nepal. In medicinal plants and their utilization. United Nations Industrial Development Organization and International Center for Science and High Technology, Trieste, Italy, Retrieved from institute.unido.org.

Ved, D.K. \& Goraya, G.S. (2011). Indian medicinal plant species of conservation concern in trade, ENVIS Center on Medicinal Plants. Foundation for Revitalization of Local Health Tradition Quarterly, 3 (1, 2, 3, \& 4), June 10, envis.frlht.org/newsletters

Vlassoff, C., Weiss, M.G., Rao, S., Ali, F., \& Prentice, T. (2013). HIV-related stigma in rural and tribal communities of Maharashtra, India. Journal of Health, Population and Nutrition, 30(4), 394-403.

Walker K. L. (2008). Neoliberalism on the ground in rural India: predatory growth, agrarian crisis, internal colonization, and the intensification of class struggle. The Journal of Peasant Studies, 35(4), 557-620. 
Wang, M. C. (2017). The relationship between firm characteristics and the disclosure of sustainability reporting. Sustainability, 9(4), 624.

Wang, Z. (2017). “Bringing the state back in": explaining women's economic empowerment in an era of globalization. Political Studies, 0032321717736743.

What is CRHP? (2014). CRHP - Comprehensive Rural Health Project. Retrieved from http://jamkhed.org/

Williams, T. C. (2017). The underlying matrices that frame divergent views in the debate on intellectual property and indigenous knowledge protection. Trans-Humanities Journal, 10(1), 81-105.

Wolf, K. D., \& Scholz, S. (2017). Health before patents: challenging the primacy of intellectual property rights. In Resistance and Change in World Politics (pp. 45-78). Palgrave Macmillan, Cham.

Zeller, C. (2008). From the gene to the globe: extracting rents based on intellectual property monopolies. Review of International Political Economy, 15(1), 86-115.

Zoramsangi, A. (2010). Local people's perspective on changes in plant species. Reflections of Climate Change Leaders from the Himalayas, 103, leadindia.org 


\section{Appendix 1}

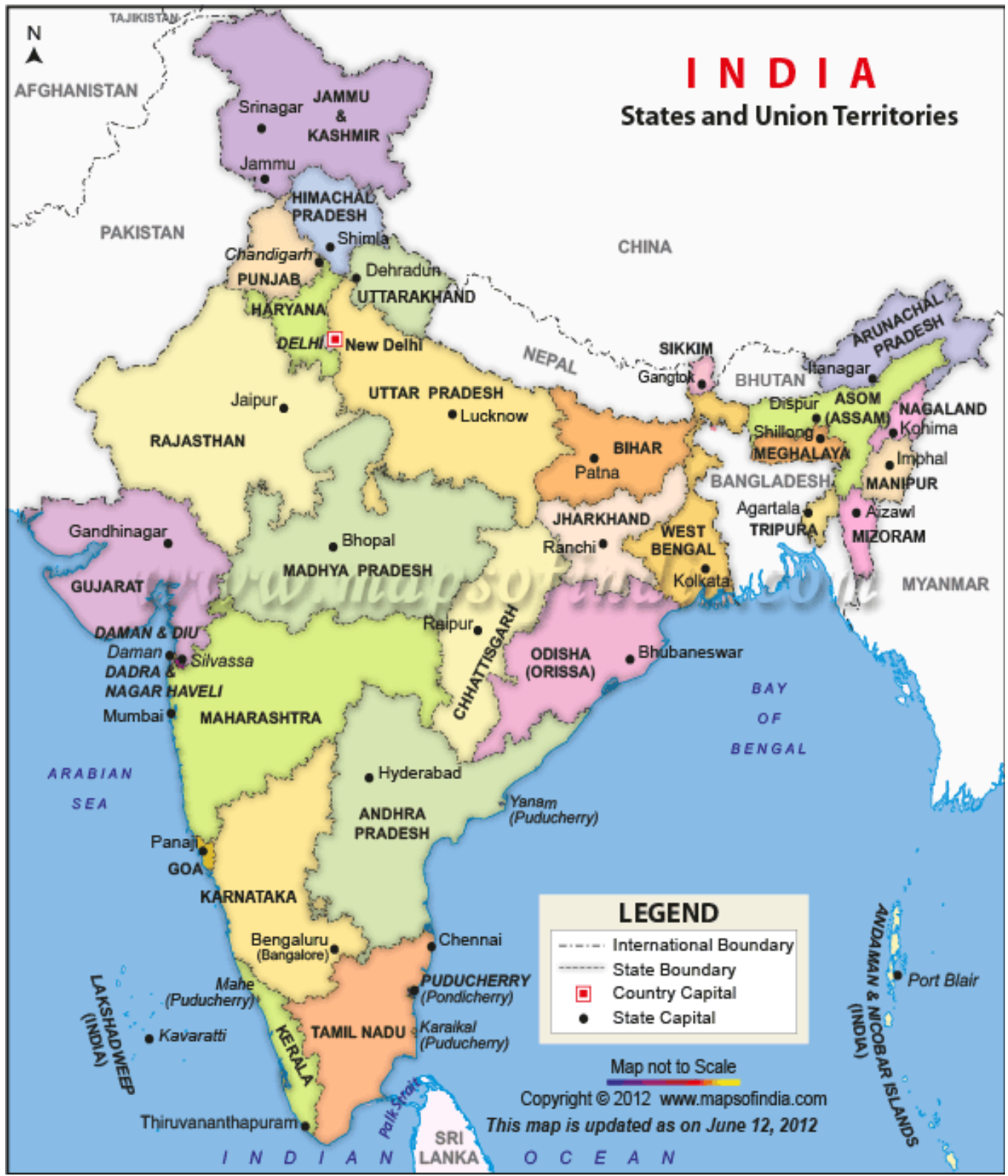




\section{Appendix 2}

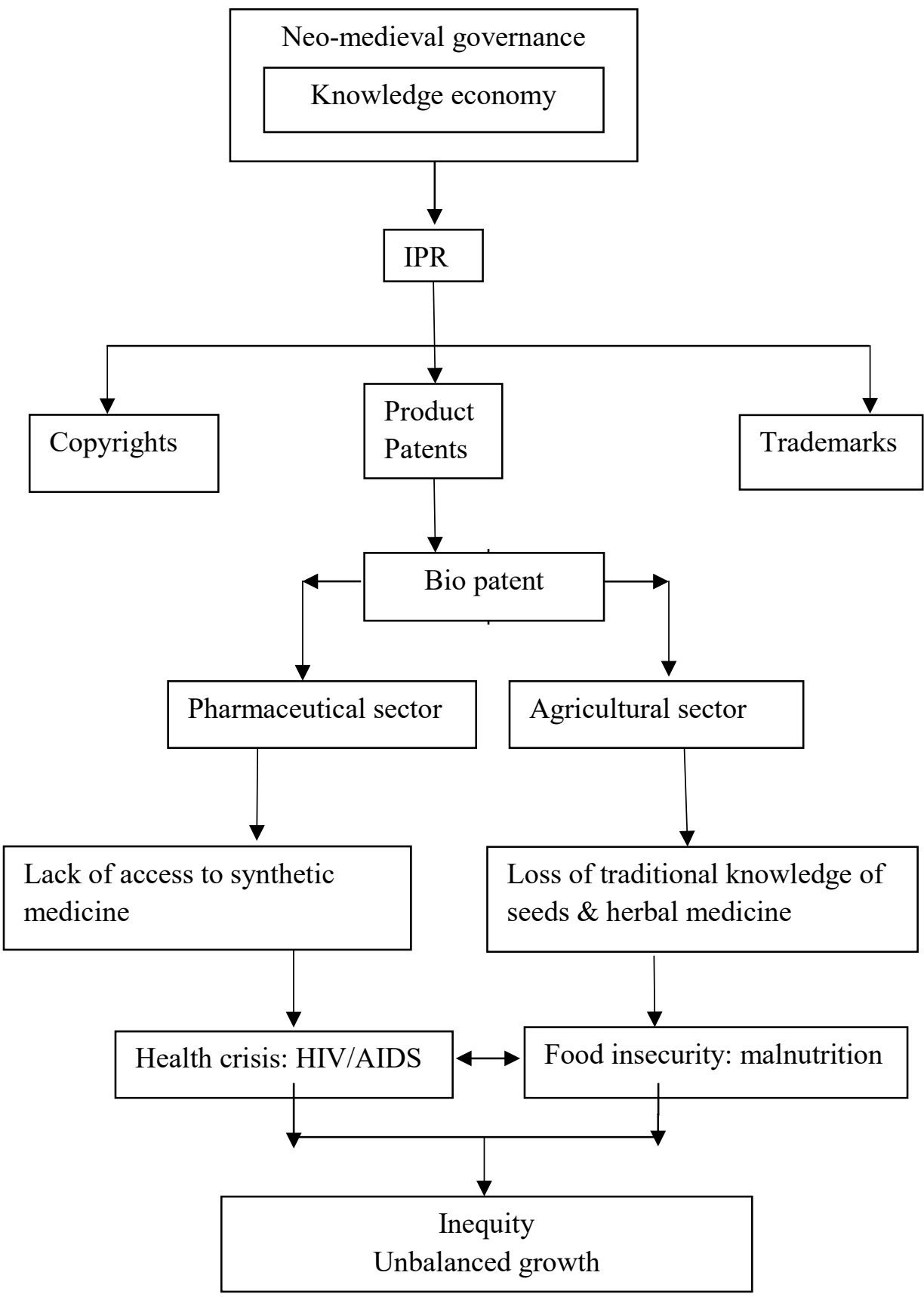

